\title{
The comparative analysis of energetic characteristics of variable-frequency electric drives with direct torque control
}

\author{
Ilya Fedotov ${ }^{1}$, Vyacheslav Tikhonov ${ }^{2}$, Evgeniy Veselkov ${ }^{3}$, Nina Seletskaya ${ }^{4}$ \\ ${ }^{1,2,3}$ Pskov State University, Electrical Engineering Faculty, \\ Department of drive and automation systems, \\ ${ }^{4}$ Pskov State University, Foreign Languages Faculty, \\ Department of Foreign Languages for the technical and economic faculties. \\ Address: Russian Federation, 180760, Pskov, Lenin Square, 2.
}

\begin{abstract}
The simulation models of variable-frequency electric drives with direct torque control were built in MATLAB / Simulink simulation environment. These models are shown and described in the article. A number of energetic characteristics of the electric drives being investigated are considered. The calculations of these characteristics were made on the computer models and the comparative analysis of the values obtained is given.
\end{abstract}

Keywords: simulation, direct torque control, vector control, harmonic spectrum, total harmonic distortion (THD), coefficient of losses increasing.

\section{INTRODUCTION}

Nowadays variable-frequency electric drives, with induction motors powered by static frequency converters are widely used. The most common frequency converters in use nowadays are indirect frequency converters including a rectifier with a filter and an inverter and having an intermediate DC link. The form of the inverter output voltage feeding the stator windings of the induction motor is different from the sine wave one. Under the nonsinusoidal voltage the harmonic spectrum, which can include high-order harmonics with sufficiently big magnitudes, appears [1]. Voltage waveform distortion results in a nonsinusoidal current waveform and causes the increase of losses in the induction motor. These factors reduce the induction motor energy efficiency $[2,3]$. When the induction motor is powered by the frequency converter its efficiency coefficient is lower by $2-$ $3 \%$ on the average, and the power coefficient - by $5 \%$ in comparison to the mains supply with the voltage sine waveform [4]. The increasing pulsations of the induction motor electromagnetic torque, which appear mainly at low frequencies and small inertia, cause problems of electromechanical compatibility of the motor and the converter.

\section{SYSTEMS OF DIRECT TORQUE CONTROL: OVERVIEW, SIMULATION MODELS.}

In up-to-date frequency converters various control strategies can be implemented. The most convenient control systems are vector systems of direct torque control. They are: vector control (VC), in which the torque is controlled while the rotor flux linkage is maintained with digital controllers for main coordinates (rotor flux linkage, d-axis and q-axis stator currents, speed), and direct torque control (DTC) wherein torque control is performed by stator flux linkage adjustment by means of relay controllers for flux linkage and torque [5].

The main theoretical statements, concerning the development of these systems and control principles being used, were shown in [6]. The simulation model of DTC system built in MATLAB / Simulink simulation environment (Fig. 1) and the principle of work of that model were also described in that article. 


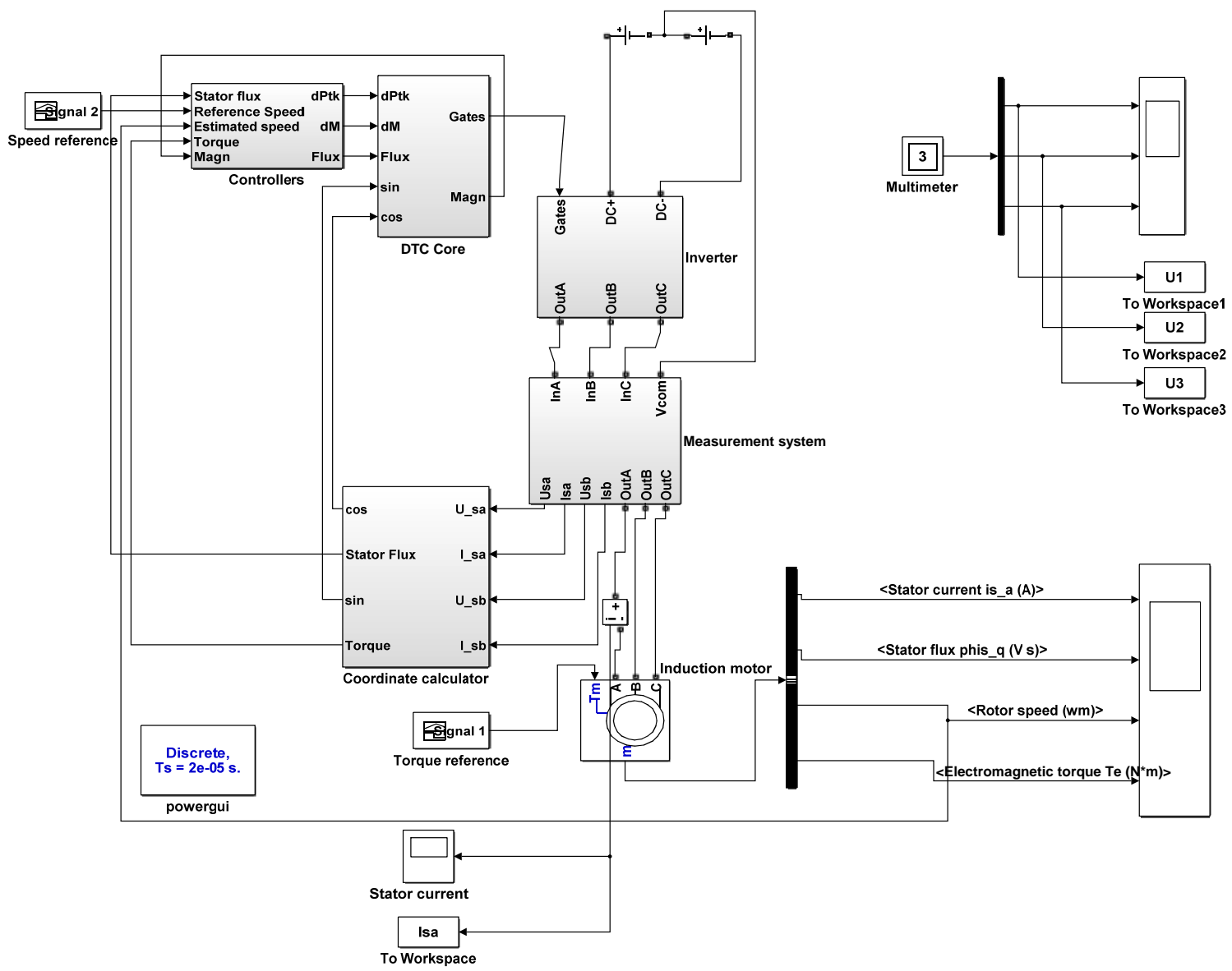

Fig. 1. Simulation model of DTC system.

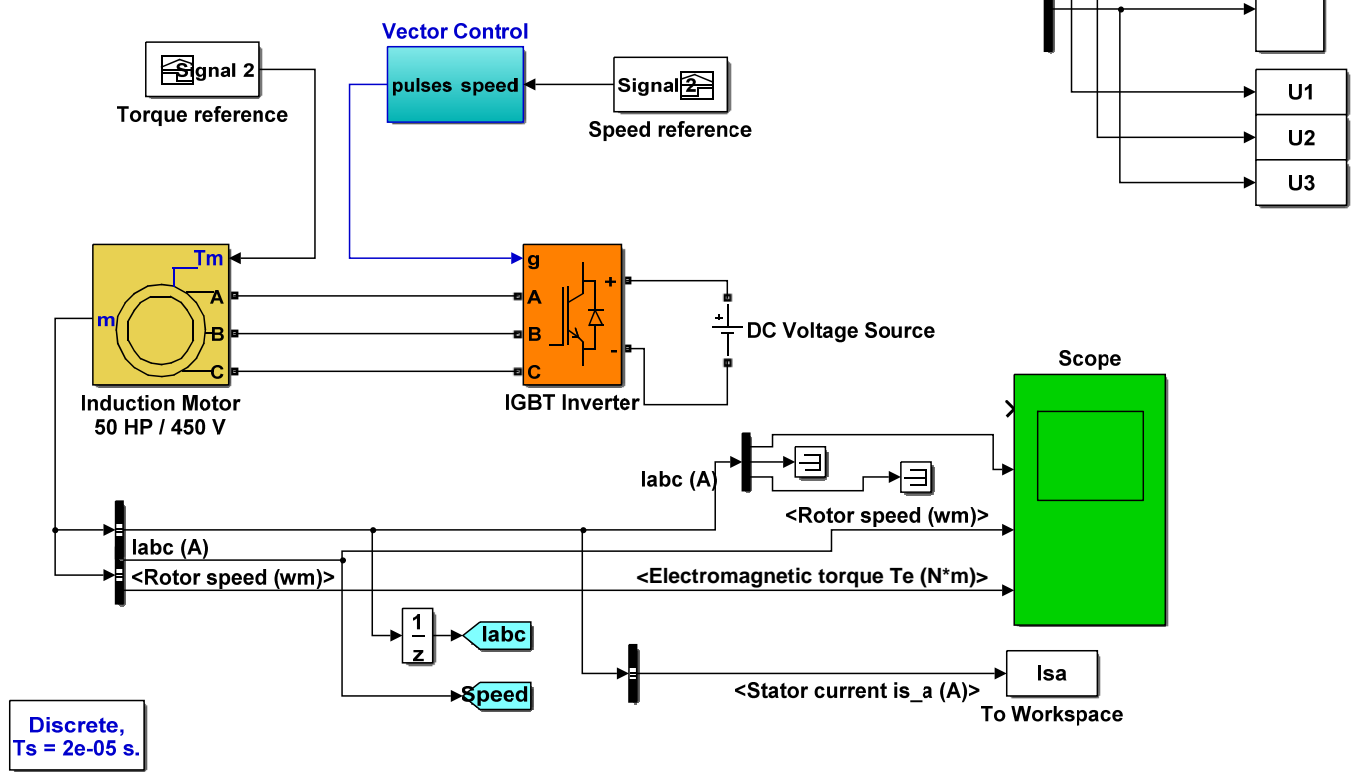

Fig. 2. Simulation model of VC system. 
The simulation model of system with VC built in MATLAB / Simulink is shown in Fig. 2. Inverter (IGBT Inverter) switch control is performed via the subsystem Vector Control by using the PI speed controller and relay current controller. The speed reference signal and signal from the current sensors positioned in the stator circuit of the induction motor are used as input signals of this subsystem. The logical signal, specifying the combination of turned-on inverter IGBT-modules, is an output signal of the subsystem.

\section{MAIN CHARACTERISTICS OF THE ENERGY EFFICIENCY OF THE SYSTEMS WITH DIRECT TORQUE CONTROL.}

The above-mentioned models are analyzed in this article from the point of view of energetic characteristics. One of the most important quality factors is known to be a total harmonic distortion of voltage $K_{U}$ and current $K_{I}$ [7]. The higher the values of these coefficients the more are constant and variable losses in the motors. High-order harmonics in the supplying voltage cause the additional heating of motors because of an increased eddy current and hysteresis losses and, as a sequence, an intensified insulation deterioration, which can result in a premature failure of the machine, if this circumstance is not taken into the account $[8,9]$.

The level of an impact of each harmonic on the voltage and current waveform quantitatively can be evaluated by the harmonics coefficient $k_{v}$ [10]:

$$
k_{v(U, I)}=\frac{U(I)_{v}}{U(I)_{1}} \cdot 100 \%,
$$

where $U(I)_{v}$ - the RMS value of voltage (current) of the $V^{\text {th }}$ harmonic;

$$
U(I)_{1} \text { - the RMS value of voltage }
$$

(current) of the $1^{\text {st }}$ harmonic.

The level of the distortion of voltage (current) waveform due to the total impact of all harmonics is evaluated by means of voltage (current) total harmonic distortion (THD) [11]:

$$
k_{U(I)}=\frac{\sqrt{\sum_{v=2}^{m} U(I)_{v}^{2}}}{U(I)_{1}} \cdot 100 \%,
$$

where $m$ is number of the highest harmonic being considered.

One more characteristic used for evaluation of energy efficiency of induction motors powered by frequency converters is a coefficient of total losses increasing $K_{\text {total }}$ what is the ratio between the losses in the motor when it is powered by pulse voltage and when it is powered by sine voltage [12]. The expression for this coefficient includes two components - the coefficient of electrical losses increasing $K_{e l}$ and the coefficient of iron losses increasing $K_{i r}$, which are calculated as follows [4]:

$$
\begin{gathered}
K_{e l}=1+K_{s c}^{2} \sum_{v=3}^{\infty}\left[\frac{1}{v}\left(\frac{U_{v}}{U_{1}}\right)^{2}\right], \\
K_{i r}=1+K_{\text {НОНС }} \sum_{v=3}^{\infty}\left[\frac{1}{v^{0,7}}\left(\frac{U_{v}}{U_{1}}\right)^{2}\right],
\end{gathered}
$$

where $K_{s c}$ is starting current-to-rated current ratio of the motor, $K_{\text {НОНС }}=(2 \div 3)$ is the coefficient of magnetic losses increasing due to high-order harmonic components of the induction motor.

For induction motors of general purpose industrial version electrical losses are in the average $60 \%$ of total losses and iron losses are $25 \%$. Taking it into consideration we can calculate $K_{\text {total }}$ as follows [4]:

$$
K_{\text {total }}=1+0,6 \cdot \hat{E}_{e l}+0,25 \cdot \hat{E}_{i r} .
$$

Analyzing energetic characteristics of variablefrequency electric drives controlled according to the above-mentioned control laws can be done, based on the stator current and voltage waveforms, obtained from the computer simulation.

\section{SIMULATION RESULTS}

Investigated were two operating modes: no-load mode $\left(M_{L O A D}=0\right)$ and the operating mode with $M_{L O A D}=0,5 \cdot \grave{I}_{\text {RATED }}$. As a result of the simulation stator current and frequency converter output voltage waveforms were obtained. These waveforms are shown in Fig. 3-6. 


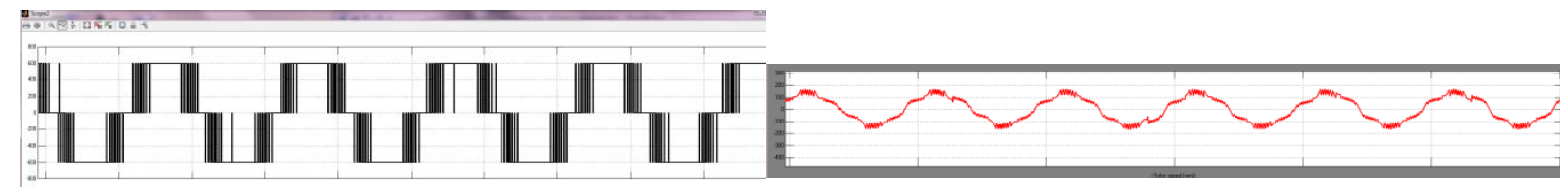

$\mathrm{b}$

Fig. 3. Waveforms of frequency converter output voltage (a) and stator current (b) in the system with vector control $\left(M_{L O A D}=0\right)$.

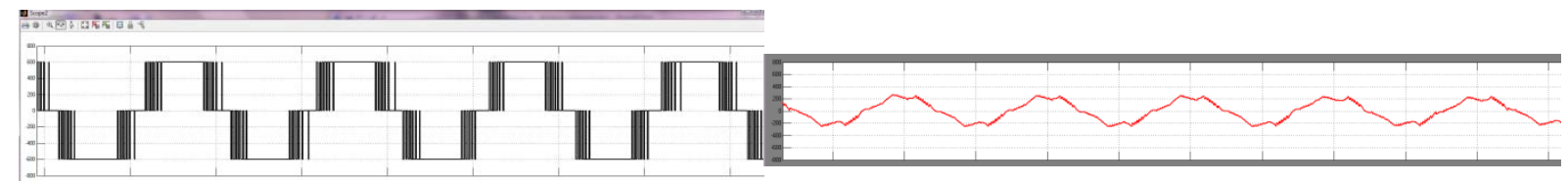

$\mathrm{b}$

Fig. 4. Waveforms of frequency converter output voltage (a) and stator current (b) in the system with vector control $\left(M_{L O A D}=0,5 \cdot \grave{I}_{R A T E D}\right)$.

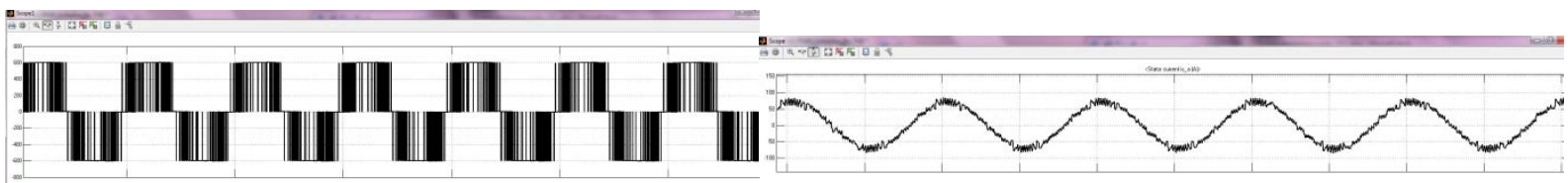

b

Fig. 5. Waveforms of frequency converter output voltage (a) and stator current (b) in the system with DTC $\left(M_{L O A D}=0\right)$.

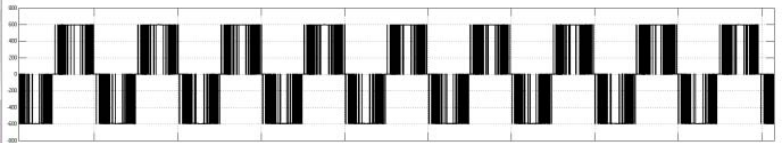

a

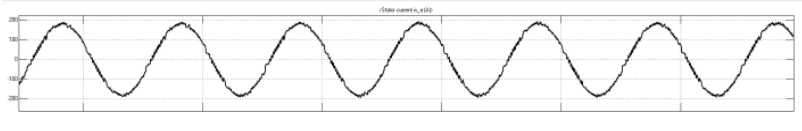

$\mathrm{b}$

Fig. 6. Waveforms of frequency converter output voltage (a) and stator current (b) in the system with DTC $\left(M_{\text {LOAD }}=0,5 \cdot \grave{I}{ }_{R A T E D}\right)$.

To analyze the harmonic spectrum of the waveforms obtained the MATLAB / Simulink standard tool - FFT Analysis, which performs the Fourier series expansion of the initial waveforms, is used.
As the results of the simulation done for the waveforms being under consideration, the harmonic spectra up to the 49-th harmonic were obtained. These results are shown in Table I.

TABLE I.

THE HARMONIC SPECTRA OF SIGNALS ( $m=49$ ).

\begin{tabular}{|c|c|c|c|c|c|c|c|c|}
\hline \multirow{3}{*}{$\begin{array}{l}\text { Harmonic } \\
\text { order }\end{array}$} & \multicolumn{4}{|c|}{$\mathrm{VC}$} & \multicolumn{4}{|c|}{ DTC } \\
\hline & \multicolumn{2}{|c|}{$M_{L O A D}=0$} & \multicolumn{2}{|c|}{$M_{L O A D}=0,5 \cdot \grave{I} \quad{ }_{R A T E D}$} & \multicolumn{2}{|c|}{$M_{L O A D}=0$} & \multicolumn{2}{|c|}{$M_{L O A D}=0,5 \cdot \grave{I} \quad$ RATED } \\
\hline & $U, \mathrm{~V}$ & $I, \mathrm{~A}$ & $U, \mathrm{~V}$ & $I, \mathrm{~A}$ & $U, \mathrm{~V}$ & $I, \mathrm{~A}$ & $U, \mathrm{~V}$ & $I, \mathrm{~A}$ \\
\hline 1 & 446,2 & 94,68 & 452 & 160,3 & 409,7 & 50,95 & 415,2 & 129 \\
\hline 3 & 4,15 & 0,97 & 2,58 & 2,64 & 1,07 & 0,42 & 1,33 & 0,67 \\
\hline 5 & 17,54 & 10,8 & 34,58 & 21,99 & 4,47 & 1,09 & 3,16 & 1,02 \\
\hline 7 & 12,14 & 4,52 & 10,49 & 6,22 & 4,06 & 0,67 & 7,68 & 1,51 \\
\hline 9 & 3,21 & 0,86 & 3,8 & 1,22 & 0,45 & 0,18 & 6,89 & 0,74 \\
\hline 11 & 8,79 & 1,92 & 18,89 & 4,81 & 7,78 & 0,77 & 8,93 & 1,08 \\
\hline
\end{tabular}


Ilya Fedotov, et al./ Environment. Technology. Resources, (2015), Volume I, 33-38

\begin{tabular}{|c|c|c|c|c|c|c|c|c|}
\hline \multirow{3}{*}{$\begin{array}{l}\text { Harmonic } \\
\text { order }\end{array}$} & \multicolumn{4}{|c|}{$\mathrm{VC}$} & \multicolumn{4}{|c|}{ DTC } \\
\hline & \multicolumn{2}{|c|}{$M_{L O A D}=0$} & \multicolumn{2}{|c|}{$M_{L O A D}=0,5 \cdot \grave{I} \quad{ }_{R A T E D}$} & \multicolumn{2}{|c|}{$M_{L O A D}=0$} & \multicolumn{2}{|c|}{$M_{L O A D}=0,5 \cdot \grave{I} \quad{ }_{R A T E D}$} \\
\hline & $U, \mathrm{~V}$ & $I, \mathrm{~A}$ & $U, \mathrm{~V}$ & $I, \mathrm{~A}$ & $U, \mathrm{~V}$ & $I, \mathrm{~A}$ & $U, \mathrm{~V}$ & $I, \mathrm{~A}$ \\
\hline 13 & 7,81 & 1,19 & 18,35 & 3,48 & 8,23 & 0,77 & 7,22 & 0,55 \\
\hline 15 & 18,56 & 0,37 & 5,24 & 1,09 & 2,46 & 0,16 & 1,83 & 0,25 \\
\hline 17 & 1,65 & 0,66 & 5,74 & 0,5 & 9,55 & 0,93 & 5,56 & 0,94 \\
\hline 19 & 5,89 & 0,38 & 10,49 & 1,33 & 7,7 & 1,04 & 9,47 & 0,52 \\
\hline 21 & 3,79 & 0,33 & 5,02 & 0,82 & 5,78 & 0,36 & 6,19 & 0,3 \\
\hline 23 & 5,35 & 0,27 & 13,33 & 1,89 & 16,96 & 1,38 & 13,12 & 1,25 \\
\hline 25 & 6,11 & 0,95 & 11,16 & 0,95 & 10,65 & 0,33 & 6,98 & 0,46 \\
\hline 27 & 4,91 & 0,44 & 2,17 & 0,63 & 2,74 & 0,31 & 15,49 & 0,62 \\
\hline 29 & 5,89 & 0,4 & 8,99 & 0,93 & 16,67 & 1,01 & 21,38 & 0,72 \\
\hline 31 & 14,99 & 1,69 & 18,94 & 1,86 & 5,9 & 0,22 & 4,82 & 0,05 \\
\hline 33 & 2,59 & 0,45 & 2,67 & 0,75 & 8,93 & 0,29 & 12,21 & 0,52 \\
\hline 35 & 7,94 & 0,77 & 16 & 1,3 & 14,5 & 0,79 & 27,61 & 0,71 \\
\hline 37 & 19,45 & 1,57 & 6,64 & 0,37 & 19,42 & 0,63 & 17,06 & 0,68 \\
\hline 39 & 8,43 & 0,39 & 2,98 & 0,21 & 12,05 & 0,42 & 17,52 & 0,58 \\
\hline 41 & 4,15 & 0,59 & 18,94 & 1,47 & 17,78 & 0,36 & 27,15 & 0,88 \\
\hline 43 & 5,13 & 0,05 & 24,59 & 1,47 & 29,87 & 1,01 & 22,59 & 0,99 \\
\hline 45 & 14,86 & 0,57 & 4,97 & 0,77 & 14,71 & 0,26 & 11,13 & 0,4 \\
\hline 47 & 20,21 & 0,84 & 19,21 & 1,38 & 9,91 & 0,2 & 3,11 & 0,27 \\
\hline 49 & 38,02 & 2,94 & 21,47 & 0,64 & 4,51 & 0,34 & 17,56 & 0,63 \\
\hline
\end{tabular}

The numerical values of THDs for the voltage and current waveforms in the systems being considered, obtained after calculation using the formula (1), are shown in Table II.

Table II.

THE VALUES OF THD.

\begin{tabular}{|c|c|c|c|c|c|c|c|}
\hline \multicolumn{4}{|c|}{$\mathrm{VC}$} & \multicolumn{4}{|c|}{ DTC } \\
\hline \multicolumn{2}{|c|}{$M_{L O A D}=0$} & \multicolumn{2}{|c|}{$\begin{array}{c}M_{L O A D}= \\
0,5 \cdot \dot{I}_{R A T E D}\end{array}$} & \multicolumn{2}{|c|}{$M_{L O A D}=0$} & \multicolumn{2}{|c|}{$\begin{array}{c}M_{L O A D}= \\
0,5 \cdot \grave{I}_{R A T E D}\end{array}$} \\
\hline $\begin{array}{c}k_{U} \\
\%\end{array}$ & $\begin{array}{l}k_{I}, \\
\%\end{array}$ & $\begin{array}{l}k_{U} \\
, \%\end{array}$ & $\begin{array}{l}k_{I}, \\
\%\end{array}$ & $\begin{array}{l}k_{U} \\
, \%\end{array}$ & $\begin{array}{l}k_{I}, \\
\%\end{array}$ & $\begin{array}{c}k_{U}, \\
\%\end{array}$ & $\begin{array}{l}k_{I} \\
, \%\end{array}$ \\
\hline 14,18 & 13,4 & 15,79 & 15,13 & $\begin{array}{c}14 \\
3\end{array}$ & $\begin{array}{c}6,4 \\
9\end{array}$ & 16,25 & 2,87 \\
\hline
\end{tabular}

For the systems being considered the calculated values of the coefficient of electrical losses increasing $K_{e l}$ and the coefficient of iron losses increasing $K_{i r}$ are obtained by using the formulae (2). These values are shown in Table III.

Table III.

THE VALUES OF $K_{e l}$ AND $K_{i r}$.

\begin{tabular}{|c|c|c|c|c|}
\hline \multirow{2}{*}{} & \multicolumn{2}{|c|}{$\mathrm{VC}$} & \multicolumn{2}{c|}{$\mathrm{DTC}$} \\
\cline { 2 - 5 } & $M_{\text {LOAD }}=0$ & $\begin{array}{c}M_{\text {LOAD }}= \\
0,5 \cdot \grave{I}{ }_{\text {RATED }}\end{array}$ & $M_{\text {LOAD }}=0$ & $\begin{array}{c}M_{\text {LOAD }}= \\
0,5 \cdot \grave{I}{ }_{\text {RATED }}\end{array}$ \\
\hline$K_{e l}$ & 1,048 & 1,097 & 1,033 & 1,043 \\
\hline
\end{tabular}

\begin{tabular}{|c|c|c|c|c|}
\hline \multirow{2}{*}{} & \multicolumn{2}{|c|}{$\mathrm{VC}$} & \multicolumn{2}{c|}{$\mathrm{DTC}$} \\
\cline { 2 - 5 } & $M_{\text {LOAD }}=0$ & $\begin{array}{c}M_{\text {LOAD }}= \\
0,5 \cdot I_{\text {RATED }}\end{array}$ & $M_{\text {LOAD }}=0$ & $\begin{array}{c}M_{\text {LOAD }}= \\
0,5 \cdot \dot{I}_{\text {RATED }}\end{array}$ \\
\hline$K_{e l}$ & 1,048 & 1,097 & 1,033 & 1,043 \\
\hline$K_{i r}$ & 1,0056 & 1,0097 & 1,0046 & 1,0059 \\
\hline
\end{tabular}

Based on the $K_{e l}$ and $K_{i r}$, the values of coefficient of total losses increasing $K_{\text {total }}$ were calculated by using the formula (3). The results obtained are shown in Table IV.

Table IV.

THE VALUES OF $K_{\text {total }}$.

\begin{tabular}{|c|c|c|c|c|}
\hline \multirow{2}{*}{} & \multicolumn{2}{|c|}{$\mathrm{VC}$} & \multicolumn{2}{c|}{$\mathrm{DTC}$} \\
\cline { 2 - 5 } & $M_{L O A D}=0$ & $\begin{array}{c}M_{\text {LOAD }}= \\
0,5 \cdot \dot{I}_{\text {RATED }}\end{array}$ & $M_{\text {LOAD }}=0$ & $\begin{array}{c}M_{\text {LOAD }}= \\
0,5 \cdot \dot{I}_{R A T E D}\end{array}$ \\
\hline$K_{\text {total }}$ & 1,03 & 1,06 & 1,021 & 1,027 \\
\hline
\end{tabular}

\section{CONCLUSIONS}

Relying on the results obtained the following conclusions can be made:

1. The values of THD for the voltage waveform are nearly constant for both systems 
considered and are slightly dependent on the load torque; they lie in the range of $(14 \div 17) \%$.

2. The simulation shows that the values of THD for the current waveform in the no-load mode for the DTC system $(6,49 \%)$ nearly are as small as twice then the corresponding values for the $\mathrm{VC}$ system $(13,4 \%)$, and in the on-load mode the values reduces to the $2,87 \%$, what makes the system energetically efficient.

3. The values of $K_{e l}$ and $K_{i r}$, obtained after simulating DTC system, are smaller than those for the VC system, and as a sequence, the coefficient of total losses increasing is also smaller.

Further research contemplates more detailed investigation of main operating modes of variable frequency electric drives with direct torque control. This research is going to be carried out by means both simulation and full-scale experiments using the test stand [13].

\section{APPENDIX}

The test machine is a three phase $50 \mathrm{~Hz}$ induction machine having the following parameters as shown in Table $\mathrm{V}$.

TABLE V.

PARAMETERS OF THE TESTED INDUCTION MACHINE

\begin{tabular}{|ll|}
\hline Parameter & Parameter value \\
\hline Power rating, $\mathrm{P}_{\text {rated }}$ & $180 \mathrm{~kW}$ \\
Rated voltage, $\mathrm{V}_{\text {rated }}$ & $450 \mathrm{~V}$ \\
Rated current, $\mathrm{I}_{\text {rated }}$ & $276 \mathrm{~A}$ \\
Pole pair, $\mathrm{p}$ & 2 \\
Torque rating, $\mathrm{M}_{\text {rated }}$ & $1150 \mathrm{~N} \cdot \mathrm{m}$ \\
Stator resistance, $\mathrm{R}_{\mathrm{s}}$ & $0,02 \Omega$ \\
Leakage stator inductive reactance, $\mathrm{x}_{\mathrm{s}}$ & $0,00967 \Omega$ \\
Rotor resistance, $\mathrm{R}_{\mathrm{r}}$ & $0,00859 \Omega$ \\
Leakage rotor inductive reactance, $\mathrm{x}_{\mathrm{r}}$ & $0,0962 \Omega$ \\
Magnetizing inductive reactance, $\mathrm{x}_{\mathrm{m}}$ & $2,6 \Omega$ \\
Inertia, $\mathrm{J}$ & $3,2 \mathrm{~kg} \cdot \mathrm{m}^{2}$ \\
\hline
\end{tabular}

\section{REFERENCES}

1. Браславский И.Я. Энергосберегающий асинхронный электропривод: учеб. Пособие для студ. Высш. Уч.
Заведений / И.Я. Браславский, З.Ш. Ишматов, В.Н. Поляков; под ред. И.Я. Браславского. - М.: Издательский центр «Академия», 2004. - 256 с.

2. Филюшов Ю.П. Энергоэффективное управление асинхронной машиной. Электротехника, №6, 2014. C. 57-65.

3. Казаков Ю.Б. Энергоэффективность работы двигателей и трансформаторов при конструктивных и режимных вариациях: учебное пособие для вузов / Ю. Б. Казаков. - М.: Издательский дом МЭИ, 2013. - 152 с.: ил.

4. Водовозов А.М., Королёв Т.В. Система оценки энергетических параметров электроприводов переменного тока. Труды VII Международной (XVIII Всероссийской) научно-технической конференции по автоматизированному электроприводу: ФГБОУ ВПО «Ивановский государственный энергетический университет имени В.И. Ленина». - Иваново, 2012. C. 96-101.

5. I. Takahashi, T. Noguchi. A New Quick-Response and High-Efficiency Control Strategy of an Induction Motor. IEEE Transactions on Industry Applications. Vol. IA-22, No. 5, PP. 820 - 827. September / October, 1986.

6. I.M. Fedotov, V.I. Tikhonov. «Simulation of traction electric drive with vector systems of direct torque control». Environment. Technology. Recourses. Proceedings of the 9th International Scientific and Practical Conference June 20-22, 2013 Volume II. - pp. 106-111.

7. Осадчук Ю.Г., Козакевич И.А., Зиненко А.Н. «Исследование энергетических характеристик частотно-регулируемых электроприводов» // Вісник КТУ. - 2008. - Вип. 20. - С. 126-130.

8. Вольдек А.И. Электрические машины: учеб. для студентов высших технических учебных заведений. 3-е изд., перераб. - Л.: Энергия, 1978. - 832 с.

9. Аррилага Дж., Брэдли Д., Боджер П. Гармоники в электрических системах. - М.: Энергоатомиздат, 1990. $-320 \mathrm{c}$.

10. Иньков Ю.М., Фадейкин Т.Н., Бредихина Я.А. «Потери мощности в асинхронных тяговых двигателях перспективного электроподвижного состава». Электротехника, №8, 2014. - С. 44-47.

11. В.М. Зырянов, Н.А. Митрофанов, Ю.Б. Соколовский. «Исследование гармонического состава напряжения преобразователя частоты». Вестник ИГЭУ, Вып. 1, 2015. - C. $1-6$.

12. Ю.Б. Казаков, А.Р. Колганов, Н.К. Швецов, Энергоэффективность асинхронного двигателя при частотном управлении с широтно-импульсной модуляцией напряжения. Труды VIII Международной (XIX Всероссийской) конференции по автоматизированному электроприводу АЭП-2014: в 2 т. / отв. за выпуск И.В. Гуляев. - Саранск : Изд-во Мордов. ун-та, 2014. - Т. 1, с. 74-78.

13. И.М. Федотов, А.А. Хитров. «Structure designing of test stand for investigation of variable frequency electric drives». Cilvēks. Vide. Tehnoloğijas: 16 starptautiskās student zinātniski praktiskās konferences rakstu krājums 2012. gada. 25. aprīlis. - pp. 448-452. 